\title{
The effects of tourism students' personality traits on leisure motivation and social well-being
}

Gulseren Yurcu

Akdeniz University

Zeki Akıncı

Akdeniz University

Murad Alpaslan Kasalak

Akdeniz University

\section{Recommended Citation}

Yurcu, G., Akıncl, Z., \& Kasalak, M. A. (2017). The effects of tourism students' personality traits on leisure motivation and social well-being. (1), 10-26.

\section{Revisions}

Submission date: Oct. 24, 2016

1st Revision: Feb. 7, 2017

2nd Revision: Feb. 20, 2017

Acceptance: Feb. 20, 2017 


\title{
The Effects of Tourism Students' Personality Traits on Leisure Motivation and Social Well-Being
}

\section{Gulseren Yurcu ${ }^{1}$, Zeki Akınci², and Murad Alpaslan Kasalak $^{3}$}

\author{
The Faculty of Tourism \\ Akdeniz University, Turkey \\ ${ }^{1}$ gulserenyurcu@akdeniz.edu.tr \\ 22zakinci@akdeniz.edu.tr \\ ${ }^{3}$ muradkasalak@akdeniz.edu.tr
}

\begin{abstract}
In today's globalized world where loneliness has increased, psychological well-being has decreased and chronic illness has become more common, participation in recreational activities is extremely important; it increases social well-being which in turn yields compliance and communication with the social environment. A high social well-being increases one's general state of happiness (Keyes, 1998). To conduct this study, we adopted the personality traits model of leisure motivation and social well-being for use as a framework. The purpose of this study is to reveal the effects of tourism students' personality traits on leisure motivation and social wellbeing. Fallowing the search, negative correlation was found between conscientiousness and social well-being, and a positive correlation was found to exist between social well-being and the variables related to personality characteristics. A positive correlation was also found between personality traits and leisure motivation. Finally, one of the dimensions of leisure motivation, intellectual factors, was negatively correlated with social well-being; the other dimensions of leisure motivation were positively correlated with social well-being.
\end{abstract}

Keywords: personality traits, leisure motivation, social well-being, tourism students

\section{Introduction}

Personality traits reveal differences in individuals' characteristics and lifestyles (Cüceloğlu, 2008; Erdoğan, 1994; Wortman, 1988). Personality traits determine feelings, thought processes and behaviors, and can be innate or gained as a result of the personal experiences. Participation in recreational activities plays an important role in personality development and especially in gaining positive character traits. Recreation and leisure also offer important contributions to individual development.

An important variable that ensures participation in recreational activities is motivation (Gökçe, 2008). The concept of motivation, which has a significant place in recreation psychology, affects the willingness of individuals to participate in leisure activities, as well as their frequency of participation. People partaking in recreational activities can achieve self-realization, gain sense 
of command, overcome obstacles, solve problems, explore, relax, and enjoy social contact with others (Üstün \& Kalkavan, 2013). In today's globalized world where loneliness has increased, psychological well-being has decreased, and chronic illness has become more common, participation in recreational activities is extremely important; it increases social well-being which in turn yields compliance and communication with the social environment. A high social well-being increases one's general state of happiness (Keyes, 1998).

To conduct this study, we adopted the personality traits model of leisure motivation and social well-being for use as a framework. This research will assist in determining the personality traits of students expected to be future tourism employees. It will also reveal the extent to which these traits influence their leisure motivation and social well-being.

\section{Literature Review}

Personality is expressed in the psycho-physical systems that determine the behaviors and thought patterns that delineate individuals' dynamic structures (Allport, 1961), as well as the consistent reactions and structured relationships one establishes with their internal and external environments; these factors all serve to distinguish individuals from one another (Bovee, Houston, \& Thill, 1995; Cüceloğlu, 2008; Morgan, 1999). Personality can be more comprehensively defined as the overall predictable behaviors that describe and introduce people (Aghaee \& Ören, 2004), the entire set of mental, emotional, and behavioral traits that demonstrate unique personal behaviors (Ordun, 2004; Tokat, Kara, \& Kara, 2013). In brief, personality, which is constantly under the influence of internal and external stimuli, includes all of an individual's psychological and biological characteristics, genetic and acquired skills, motives, emotions, desires, habits, differences, and behaviors, and reflects them through mannerisms and other lifestyle characteristics (Erdoğan, 1994; Tinar, 1999; Wortman, 1988).

Personality is a complex unity formed by a large number of features. Therefore, it is extremely difficult to analyze; it develops in a variety of ways, from the effects of different dynamics. There are many factors that affect personality traits, causing countless individual differences; these traits include biological and cultural factors during formative years, family, community, friends (Tokat et al., 2013), geographical and physical factors (Develioğlu \& Tekin, 2013), mass media and the amount of exposure to same (Erdoğan, 1994), perceptions, habits, mentality and desires (Günel, 2010). Various different classifications of personality can be found in the literature. The following theories are examples of some these classifications: The personality theories of Sigmund Freud, Eric Berne, Carl Jung, Alfred Adler, Hans J. Eysenck, Karen Horney, John L. Holland, Meyer Friedman as well as Ray H. Roseman's A and B personality types, and Warren Norman's five-factor model which is based on extraversion, agreeableness, conscientiousness, neuroticism and openness to experience. In this study, Norman's five-factor model (FFM) theory of personality was used. This model is often applied in the literature because it is based on longitudinal and empirical studies, the measured features preserve their continuities against time, it has some biological basis, its validity has been evidenced for different cultures and groups, and it's easy to use and evaluate psychometrically (McCrae \& Costa, 1992). Costa and McCrae (1995) defined the five sub-dimensions that comprise FFM as extraversion, neuroticism, agreeableness, openness to experience, and conscientiousness. These sub-dimensions are briefly explained below. 
Individuals with high extraversion levels interact easily with people. They enjoy, being in groups, are open to cooperation, sympathetic, energetic, talkative, warmhearted, excited, enthusiastic, ambitious, and passionate high performer, who respond well to awards and tent to be dominant socially. Conversely, individuals with low extraversion levels tend to be introverts who avoid social engagements and remain aloof in crowds, and who are apt to be quiet and shy with strangers (Benet-Martinez \& John, 1998; Lucas, Diener, Gro, Suh, \& Shao, 2000; Moody, 2007; Somer, Korkmaz, \& Tatar, 2002; Trouba, 2007). Individuals with high neuroticism levels are anxious, insecure, quick to anger, and resentful, whereas individuals with low levels of neuroticism are comfortable and emotionally stable, remain calm in stressful situations, are slow to anger, have high self-esteem, and are generally positive (Costa \& McCrae, 1995; Somer et al., 2002). Individuals with high levels of agreeableness are cooperative, helpful, forgiving, kind, tolerant and flexible, while those weak in agreeableness are contrary critical disagreeable, vindictive, arrogant, and contentious (Bacanl1, İlhan, \& Aslan, 2009; Costa \& McCrae, 1995; Moody, 2007; Perry, 2003 Somer et al., 2002). Individuals with high levels of conscientiousness are responsible, honest, reliable, persistent, and seek attention. They are likely to be successful, ambitious, organized, attentive and careful think before acting, and have a sense of duty. Individuals with low levels of conscientiousness tend to be untidy, undisciplined, irresponsible, unreliable, lazy, forgetful, callous, careless and have no sense of duty (Church, 1993; Costa \& McCrae, 1995). Individuals with openness to experience are clever, imaginative, creative, productive, artistic, curious, open to new ideas, have active imaginations, are open to change, and willing to exercise independent judgment (Church, 1993; Jia, 2008). Individuals without an openness to experience are conservative, traditional, hardcore, and not-innovative (BenetMartinez \& John, 1998; Costa \& McCrae, 1995; Somer et al., 2002).

Motivation can be biological, physiological, or cultural; it is what impels the human organism to engage in a particular behavior, determines the intensity and energy level associated with that behavior, gives it direction, and decides how the actor accommodates internal and external causes that provide continuance (Eren, 2006; Kılınç, Ulucan, Kaya, \& Türkçapar, 2012; Mutlu, Y1lmaz, Güngörmüş, Sevindi, \& Gürbüz, 2011). Motivation not only provides the individual with the will to reach their aim, but the energy necessary to maintain that will. Thus, motivation has two dimensions. The first is the determination and excitement to address and pursue the goal; the second is the preservation of that energy throughout the entirety of the pursuit (Barl1, 2008). Motivation can also change direction and level of intensity over time (Mutlu et al., 2011). The concept of motivation is often addressed in the literature of recreational psychology. It affects people's participation in recreational activities, their frequency of involvement, and how partaking affects other factors that influence their lives (Gökçe, 2008). The most important reasons to take part in refreshing and entertaining recreational activities is to joyfully engage in leisure, interact with friends, do something different from one's daily work gain new experiences, taste the feeling of success, embrace creativity, and reap social benefits (Emir, 2012).

Functionally, leisure behaviors remain under the influence of two simultaneous motivational forces. One is to escape the monotony and ordinariness of everyday life proximate environment, and usual circle of personal and interpersonal relations. The other is to participate in leisure activities and enjoy the resulting psychological rewards such as self-identification, dominance, superiority, struggle, advancement, discovery, relaxation, and interpersonal-social 
communication. Impulses, and thus the type and level of motivation, determine the recreational activities people choose (Üstün \& Kalkavan, 2013). Internal and external stimuli cause this motivation, which in turn allows for the individual to overcome any obstacles he or she might face. Internal motivation creates interest and curiosity; external motivation provides access to exclusive results (Mutlu et al., 2011). Conversely, a lack of motivation does not prompt people to

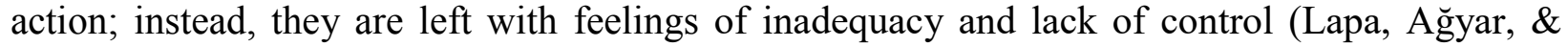
Bahadir, 2012).

There are four sub-dimensions of leisure motivation. The first is intellectual factors which represent mental activities that motivate people to participate in leisure activities; they include a will to discover, satisfy curiosity, learn new things, and use creative powers. Social factors include the need to make friends and engage in interpersonal relationships as a means of overcoming loneliness. Competence/mastery includes the desire to solve problems, deal with hardships, compete, and succeed. Stimulus/avoidance involves increasing physical, social, and psychological well-being in everyday life.

Socially healthy people can see that they and others like them benefit from social development (Keyes, 1998). Individuals who are socially healthy, in other words, are happy with society. In the literature, the term "social health" is associated with individual, societal, and economic aspects. It is also incorporated into ideas such as social, subjective, personal, or psychological well-being, and happiness. Breslow (1972) addressed social health as it intersected with notions of employability, marital satisfaction, social engagement, and social attendance, and defined an individual' social health as a dimension of well-being that affects how one gets along with others, people's reaction to that person, and their interactions with social institutions and traditions. Social well-being has been described in different ways by other researchers. Bloom (1976) identified social well-being as positive social behaviors, while Sintonen (1981) considered it to be equivalent to social participation. Interestingly, Keyes (1998) identified social well-being as a person's evaluation of his or her status and functions in the community, and subdivided it into the five dimensions of social integration, acceptance, contribution, actualization and coherence. These five sub-dimensions are explained below.

Social integration represents one's bond with society. Healthy individuals are aware that they are part of a community, and that this connection is important to all involved. Social acceptance is the social construction of the quality and character of others. People who are socially accepting believe in others; that people are affectionate and hardworking. Social individuals adopt positive impression of human nature and feel comfortable with being around others. Social contribution reflects the extent to which people will be of benefit to society. Social actualization evaluates the potential and direction of society. It is a belief in the importance of citizenship and social institutions, and a sense of community. Healthy individuals are hopeful about the future of society and are capable of seeing its potential of society. Finally, social coherence not only encapsulates an understanding of the quality, organization, and functions of the social world, but also knowledge about that world. Healthy people are concerned not only with the state of the world they live in, but also with the world beyond. Such people don't deceive themselves into believing that they live in a perfect world; they preserve and support the logic of life (Keyes, 1998). Well-being is related not only to the concept of subjective well-being, but also social well-being. A person's physical, psychological and social well-being must be high if they are to 
be described as healthy. There is a positive relationship between personality traits and social well-being, as evidenced in the literature. Based on the prior research in this area, we propose the following hypotheses:

- H1: There is a statistically significant difference between students' perceptions of social well-being and their demographics.

- H2: There is a positive relationship between students' personality traits, leisure motivation and perceptions of social well-being.

- H3: Students' personality traits positively affect their leisure motivation.

- H4: Students' personality traits positively affect their perceptions of social well-being.

- H5: Students' leisure motivations positively affect their perceptions of social well-being.

\section{Methods}

This research initially addressed 2,157 students registered in the College of Tourism at Akdeniz University. A total of 516 students were contacted. Data were collected through questionnaires distributed during the fall semester of the 2016 academic year. The questionnaire was designed to collect data falling into four key categories. In the first, information regarding the demographics of the students related to age, gender, nationality, class, income, reside and parents was collected. In the second, the Big Five Personality Scale (BFPS) developed by John, Donahue, and Kentle (1991) and employed by John and Srivastava (1999) was used to determine the student's personality traits. It is comprised of 44 items and five dimensions (extraversion, agreeableness, conscientiousness, neuroticism, openness). In this research, a five-point Likerttype scale was used, where $1=$ Completely disagree, $2=$ Slightly disagree, $3=$ Undecided, $4=$ Somewhat agree, and 5= Completely agree.

The distribution of the 44 items, dimensions, and reverse scored items were as follows: extraversion: 1, 6R, 11, 16, 21R, 26, 31R, 36; agreeableness: 2R, 7, 12R, 17, 22, 27R, 32, 37R, 42; conscientiousness: 3, 8R, 13, 18R, 23R, 28, 33, 38, 43R; neuroticism: 4, 9R, 14, 19, 24R, 29, 34R, 39; openness: 5, 10, 15, 20, 25, 30, 35R, 40, 41R, 44. The third section of the questionnaire included the leisure motivation scale used by Beggs and Elkins (2010) to determine student's leisure motivation. The scale had 32 items and four dimensions; it used a five-point Likert-type scale where $1=$ Completely disagree, $2=$ Disagree, $3=$ Undecided, $4=$ Agree, and 5=Completely agree. The fourth section utilized the short form of the social well-being scale developed by Keyes (1998) to measure students' social well-being. It was translated into Turkish by Akın, Demirci, Çitemel, Sarıçam, \& Ocakçı (2013) and also used by Tekin (2014).

A confirmatory factor analysis was employed to analyze the construct validity and reliability of the Turkish version of the form; it was determined that a social well-being model with a single dimension offered a better level of harmony than the original model consisting of five dimensions $\left(X^{2}=155.46, \mathrm{sd}=86, \mathrm{p}=.00001\right.$, RMSEA=.054, GFI=.93, AGFI=.90, SRMR=.065). The Cronbach's alpha reliability coefficient for the Turkish form of the social well-being scale was .64. The scale was a seven-point Likert-type where $1=$ Completely disagree, $2=$ Mostly Disagree, $3=$ Slightly disagree $4=$ Undecided, $5=$ Sometimes agree and $6=$ Mostly agree, and $7=$ Completely agree. The scale consisted of 15 items, had one dimension, and gave a general social well-being score. Eight items on the scale (1, 2, 7, 8, 9, 10, 13, and 15) were reverse (-) scored. Data collected via the questionnaire were analyzed through the SPSS statistical analysis software package program. 
A Kolmogorov-Simirnov test was conducted as a multivariate analysis to determine if the data were normally distributed. The results indicated that the data had a normal distribution; consequently, parametric tests were applied. A Cronbach's alpha reliability analysis was used to measure the reliability of the personality, leisure motivation, and social well-being scales; frequency and descriptive statistics were used for the personal information. A factor analysis was performed to test the validity of the personality and leisure motivation scales. A Pearson's correlation analysis was conducted to determine the relationships among personality, motivation, and social well-being. Finally, a linear regression analysis determined the effects of the variables had on one another. An independent sample t-test was performed to test hypotheses $\mathrm{H} 2, \mathrm{H} 3$, and H7. A one-way ANOVA test was used to test hypotheses H1, H4, H5, and H6. A Pearson's correlation analysis tested hypothesis $\mathrm{H} 8$, and a simple linear regression analysis examined hypotheses H9, H10, and H11. In accordance with these hypotheses, the empirical model was established (see Figure 1).

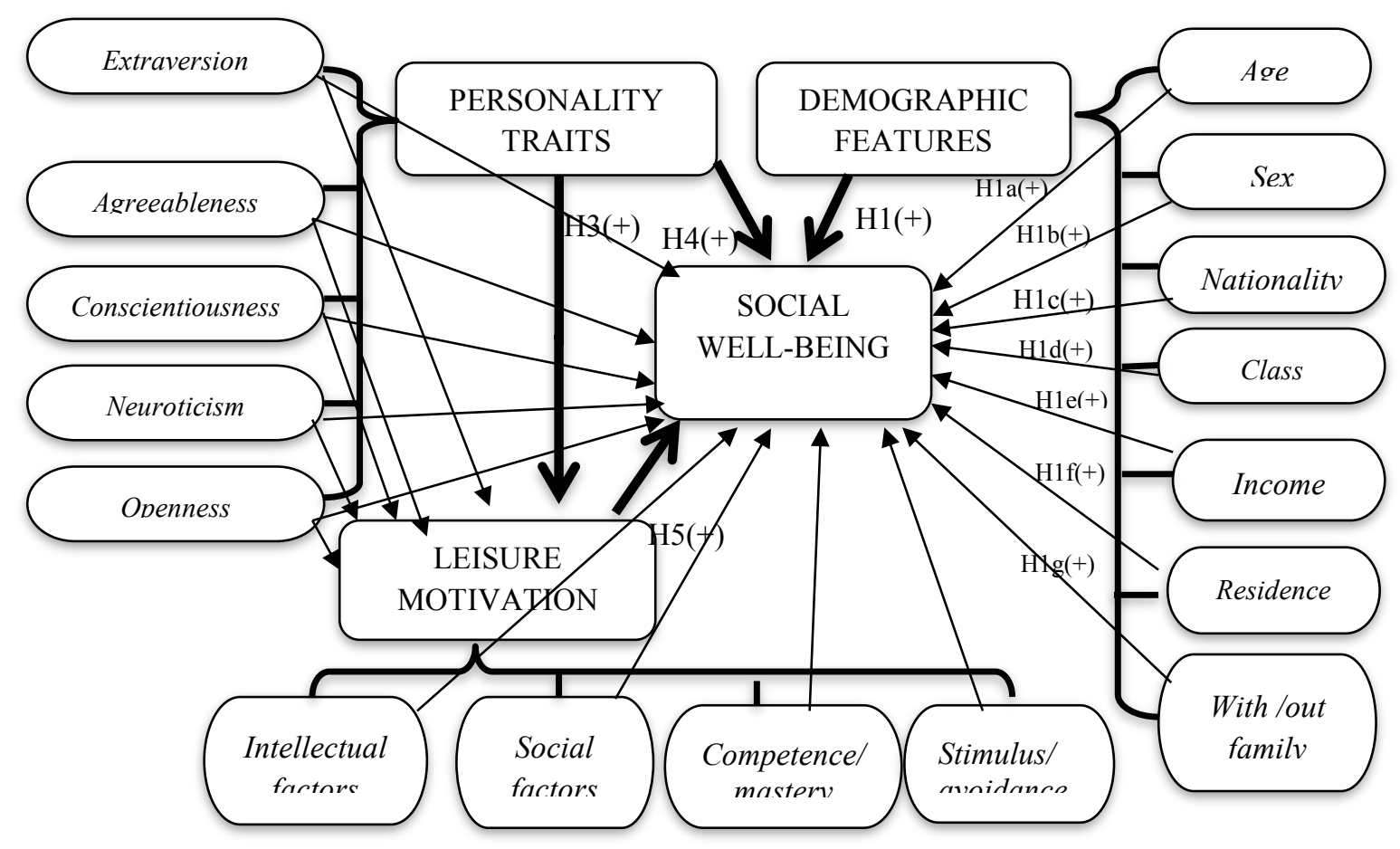

Figure 1: The empirical model

\section{Findings}

This section presents the data obtained as a result of the analysis conducted for this study. An Alpha $(\alpha)$ model (a Cronbach's Alpha coefficient) was used in the reliability analyses of the scales. The Cronbach's Alpha coefficient was 0.86 in the general validity and reliability analyses, and 0.69 for the personality trait, 0.93 for the leisure motivation and, 0.51 for the social well-being scales, respectively. The general Cronbach's Alpha values for the scales, 0.86, indicated a high level of reliability.

A factor analysis was performed to test the construct validity of the personality scale. A KaiserMeyer-Olkin (KMO) test was carried out to test the adequacy of the sample size and a Barlett 
sphericity test was conducted to determine whether or not the variables had a normal distribution. The KMO value of the personality scale was 0.825 , and the Barlett sphericity test results were meaningful. After a factor analysis and varimax rotation, five dimensions of the personality scale whose eigenvalues were greater than one were identified; these five dimensions accounted for $61.445 \%$ of the total variance. Table 1 lists the personality factors gathered.

Table 1: Personality Factor Analysis

\begin{tabular}{|c|c|c|c|c|}
\hline Variables & Statements & $\begin{array}{l}\text { Factor } \\
\text { Loading }\end{array}$ & $\begin{array}{c}\text { Factor } \\
\text { Validity }\end{array}$ & $\begin{array}{c}\text { Factor } \\
\text { Variance }\end{array}$ \\
\hline \multirow{9}{*}{ Extraversion } & 1. Is talkative & .647 & \multirow{9}{*}{.79} & \multirow{9}{*}{19.473} \\
\hline & 4. Is depressed, blue & .514 & & \\
\hline & 6. Is reserved & .725 & & \\
\hline & 11. Is full of energy & 668 & & \\
\hline & 21 . Tends to be quiet & .748 & & \\
\hline & 26. Has an assertive personality & .688 & & \\
\hline & 27. Can be cold and aloof & .549 & & \\
\hline & 31. Is sometimes shy, inhibited & .527 & & \\
\hline & 36. Is outgoing, sociable & .728 & & \\
\hline \multirow{3}{*}{ Conscientiousness } & 3. Does a thorough job & .847 & \multirow{3}{*}{.76} & \multirow{3}{*}{11.578} \\
\hline & 28. Perseveres until the task is completed & .799 & & \\
\hline & 33. Does things efficiently & .714 & & \\
\hline \multirow{3}{*}{ Openness } & 30. Values artistic, aesthetic experiences & .824 & \multirow{3}{*}{.75} & \multirow{3}{*}{11.086} \\
\hline & 41. Has few artistic interests & .871 & & \\
\hline & 44. Is sophisticated in art, music, or literature & .839 & & \\
\hline \multirow{4}{*}{ Agreeableness } & 12. Starts quarrels with others & .707 & \multirow{4}{*}{.68} & \multirow{4}{*}{10.189} \\
\hline & 32. Is considerate and kind to almost everyone & 619 & & \\
\hline & 37. Is sometimes rude to others & .706 & & \\
\hline & 42. Likes to cooperate with others & .507 & & \\
\hline \multirow[t]{2}{*}{ Neuroticism } & 19. Worries a lot & .655 & \multirow{2}{*}{.48} & \multirow{2}{*}{9.118} \\
\hline & 39. Gets nervous easily & .735 & & \\
\hline \multicolumn{2}{|c|}{$\begin{array}{l}\text { KMO: } 0.825 \\
\text { P: .000 (Barlett's test) }\end{array}$} & & \multicolumn{2}{|c|}{ Total Variance: 61.445} \\
\hline
\end{tabular}

The items whose values were below 0.50 in the factor analysis $(2,5,7,8,9,10,13,14,15,16$, $17,18,20,22,23,24,25,29,34,35,38,40$, and 43 ) were excluded. In addition, the $4^{\text {th }}, 6^{\text {th }}, 12^{\text {th }}$, $21^{\text {th }}, 27^{\text {th }}, 31^{\text {th }}, 37^{\text {th }}$, and $41^{\text {th }}$ items were reserve scored. The positive Cronbach's Alpha values for the first four factors were over $60 \%$, which indicated that the scale was quite reliable. Only neuroticism, the fifth dimension, which had an acceptable value of .48 was thought not to affect the general reliability. The validations of the dimensions of the scale were identified as: .79 for extraversion, .76 for conscientiousness, .75 for openness, .68 for agreeableness, and .48 for neuroticism.

A factor analysis was performed to test the construct validity of the leisure motivation scale. A Kaiser-Meyer-Olkin (KMO) test was carried out to test the adequacy of the sample size, and a Barlett sphericity test was conducted to determine whether or not the variables had a normal distribution. The KMO value of the leisure motivation scale was 0.916, and the Barlett sphericity test results were meaningful. After the factor analysis and varimax rotation, four dimensions were identified whose eigenvalues for the leisure motivation scale were greater than 1 . These four dimensions accounted for $63.638 \%$ of the total variance. Table 2 displays factors associated with leisure motivation. 
Table 2: Factor Analysis for Leisure Motivation

\begin{tabular}{|c|c|c|c|c|}
\hline Variables & Statements & $\begin{array}{l}\text { Factor } \\
\text { Loading }\end{array}$ & $\begin{array}{l}\text { Factor } \\
\text { Validity }\end{array}$ & $\begin{array}{l}\text { Factor } \\
\text { Variance }\end{array}$ \\
\hline & 17.To test my skills & .605 & \multirow{8}{*}{.90} & \multirow{8}{*}{19.007} \\
\hline & 18.To be good at this activity & .560 & & \\
\hline Competence $\backslash$ & 19.To improve my ability and skill in this area & .570 & & \\
\hline Mastery & 20.To be active & .632 & & \\
\hline \multirow[t]{4}{*}{ Factors } & 21. To improve my physical skill and ability & .763 & & \\
\hline & 22. To get physically fit & .774 & & \\
\hline & 23. To use my physical skills & .783 & & \\
\hline & 24. To improve my physical fitness & .770 & & \\
\hline \multirow{6}{*}{$\begin{array}{l}\text { Intellectual } \\
\text { Factors }\end{array}$} & 1. To obtain information about my surroundings & .705 & \multirow{6}{*}{.87} & \multirow{6}{*}{18.149} \\
\hline & 2.To satisfy my curiosity & .734 & & \\
\hline & 3.To discover new ideas & .756 & & \\
\hline & 5.To expand my knowledge & .783 & & \\
\hline & 6. To discover new things & .766 & & \\
\hline & 7.To be creative & 676 & & \\
\hline & 27.To relax physically & .694 & \multirow{5}{*}{.84} & \multirow{5}{*}{13.715} \\
\hline Stimulus $\backslash$ & 28.To relax mentally & .756 & & \\
\hline Avoidance & 29. To avoid the hustle and bustle of daily routine & .787 & & \\
\hline \multirow[t]{2}{*}{ Factors } & 30. To rest & .777 & & \\
\hline & 31.To relieve stress and tension & .717 & & \\
\hline \multirow{4}{*}{$\begin{array}{l}\text { Social } \\
\text { Factors }\end{array}$} & 9. To form friendships & .832 & \multirow{4}{*}{.86} & \multirow{4}{*}{12.767} \\
\hline & 10. To communicate with others & .818 & & \\
\hline & 11.To form close friendships & .797 & & \\
\hline & 12.To meet new and different people & .735 & & \\
\hline $\begin{array}{l}\text { KMO: } 0.916 \\
\text { P: .000 (Barl }\end{array}$ & t's test) & & \multicolumn{2}{|c|}{$\begin{array}{l}\text { Total Variance: } \\
63.638\end{array}$} \\
\hline
\end{tabular}

Statements whose value were below 0.50 in the factor analysis (4., 8., 13., 14., 15., 16., 25., 26., and 32.), were excluded. The Cronbach's Alpha values for these factors were positive and over $80 \%$, indicating that the scale was quite reliable. The validities of the dimensions of the scale were: identified .90 for competence/mastery, .87 for intellectual factors, .84 for stimulus/avoidance, and .86 for social factors.

After examining the participants' personal information, it was found that $97.7 \%$ were between the ages of 18 and 26; they were 58.5\% male and 40.5\% female. In total, 91.9\% were Turkish citizens, and 5.6\% were foreign nationals. More participants lived with their families $(73.4 \%)$ than did not (23.4\%). Regarding annual income level: $26 \%$ made less than 500t1, 30.2\% made between 500 and 1000tl, 16,0\% made between 1,001 and 1,500tl, 8.7\% made between 1,500 and $2,000 \mathrm{tl}$, and $13,0 \%$ made above $2,001 \mathrm{t}$. With regards to class $22.5 \%$ were freshmen, $23.8 \%$ were sophomores, $23.6 \%$ were junior, and $28.7 \%$ were senior. Of the total number of participants $60.7 \%$ resided in cities, $28.7 \%$ in towns, and $8.7 \%$ in villages.

The mean value of social well-being for students under 18 age was $(\overline{\mathrm{X}}=3.6000)$, it was $(\overline{\mathrm{X}}=4.2071)$ for students aged 18 to 26 , and $(\overline{\mathrm{X}}=4.1230)$ for ages 27 to 35 . Thus hypothesis: Hla: There is a statistically significant difference between students' perceptions of social well-being and their age was rejected. Perceptions of social well-being did not appear to vary across age groups $\left.\left(\mathrm{F}_{(2 ; 510)}\right)=2.137, \mathrm{p}>0.05\right)$. 
With regards to the participants' sex, no difference was observed in the mean values for perceptions of well-being for women $(\bar{X}=4.2432)$ and men $(\bar{X}=4.1667)$; however, female students did have higher levels of social well-being than their male counterparts. According to the t-test conducted to evaluate the significance of students' gender to their perceptions of social wellbeing, was not significant $(\mathrm{t}=1.290, \mathrm{p}>0.05)$. In this case, hypothesis $\mathrm{H} 1 \mathrm{~b}$ : There is a statistically significant difference between students' perceptions of social well-being and their gender was rejected.

In terms of nationality, no difference was found in the mean values for perceptions of social well-being between Turkish participants $(\overline{\mathrm{X}}=4.1983)$ and foreign nationals $(\overline{\mathrm{X}}=4.1355)$. According to the t-test performed to reveal the significance of students' nationalities their perceptions of social well-being, the difference was not found to be meaningful ( $\mathrm{t}=0.494$, $\mathrm{p}>0.05)$. In this case, hypothesis H1c: There is a statistically significant difference between the students' perceptions of social well-being and their nationality was rejected.

The mean values for students' social well-being by class was $(X=4.1848)$ for freshmen, $(\bar{X}=4.2049)$ for sophomores, $(\bar{X}=4.1897)$ for juniors and $(\bar{X}=4.2151)$ for seniors. Thus, the perception of social well-being did not change per class. In this case, hypothesis H1d: There is a statistically significant difference between students' perceptions of social well-being and their class was rejected. Students' perceptions of social well-being did not differ by class (F $(3 ; 508)$ )$=0.58, \mathrm{p}>0.05)$.

The mean values for students' perceptions of social well-being were $(\overline{\mathrm{X}}=4.1370)$ for students making 500tl or less per month, $(\bar{X}=4.1895)$ for those making between 500 and 1,000tl, $(\bar{X}=4.2909)$ for those between 1,001 and $1,500 t$ t, it was $(\bar{X}=4.1957)$ for those between 1,501 2,000tl, and ( $\overline{\mathrm{X}}=4.2202)$ for students making 2,001tl per month or above. Therefore, students' social well-being was not found to differ depending on their income. As a result, hypothesis Hle: There is a statistically significant difference between students' perceptions of social wellbeing and their income was rejected. The results suggest that students' perceptions of social well-being do not vary according to income $\left.\left(\mathrm{F}_{(4 ; 478)}\right)=0.706, \mathrm{p}>0.05\right)$.

With regards to place of residence the mean values for students' perceptions of social well-being based on where they live were $(\bar{X}=4.2861)$ for those residing in villages, $(\bar{X}=4.1557)$ for those in towns, and $(\overline{\mathrm{X}}=4.2105)$ for students in cities. Therefore, students' social well-being did not appear to differ depending on where they lived. In this case, hypothesis H1f: There is a statistically significant difference between students' perceptions of social well-being and where they reside was rejected. In short, students' perceptions of social well-being did not appear to vary based on where they lived $\left.\left(\mathrm{F}_{(2 ; 501)}\right)=0.756, \mathrm{p}>0.05\right)$.

There was no difference in the mean values for the students' perceptions of social well-being between students who lived with their parents $(\bar{X}=4.2530)$ and those who did not $(\bar{X}=4.1714)$. According to the t-test performed to reveal the significance of living with their parents to their perceptions regarding social well-being, the difference was not considered meaningful ( $\mathrm{t}=1.182$, $\mathrm{p}>0.05)$. Thus hypothesis HIg: There is a statistically significant difference between students' perceptions of social well-being and whether or not they live with their parents was rejected. 
The relationship connecting personality, leisure motivation and perception of social well-being were examined via a Pearson's correlation technique. In the correlation table (Table 3), it can be seen that the mean values were $(\bar{X}=3.4147)$ for personality, $(\bar{X}=3.8297)$ for leisure motivation, $(\bar{X}=4.2014)$ for social well-being, $(\bar{X}=3.0748)$ for extraversion, $(\bar{X}=3.9331)$ for conscientiousness, $(\bar{X}=3.2434)$ for openness, $(\bar{X}=3.2724)$ for agreeableness, $(\bar{X}=3.2074)$ for neuroticism, $(\bar{X}=3.8716)$ for competence/mastery, $(\bar{X}=3.9389)$ for intellectual factors, $(\bar{X}=4.0138)$ for stimulus/avoidance and $(\overline{\mathrm{X}}=3.6704)$ for social factors. The mean value for extraversion was lower than the mean values of the other variables. Also, there was a positive relationship between personality and leisure motivation (leisure motivation, $\mathrm{r}=0.490$ and $\mathrm{p}>0.01$ ). In addition, there was a positive relationship between leisure motivation, and its dimensions, and personality (competence/mastery, $\mathrm{r}=0.379$ and $\mathrm{p}>0.01$; intellectual factors $\mathrm{r}=0.499$ and $\mathrm{p}>0.01$; stimulus/avoidance, $\mathrm{r}=0.287$ and $\mathrm{p}>0.01$ and, social factors, $\mathrm{r}=0.288$ and $\mathrm{p}>0.01$ ). There was a positive relationship between personality and social well-being (social well-being, $\mathrm{r}=0.149$ and $\mathrm{p}>0.01)$.

In addition, there was a positive relationship between personality certain of its dimensions (extraversion, openness, agreeableness, and neuroticism), and social well-being, and a negative relationship between conscientiousness and social well-being (extraversion, $\mathrm{r}=0.156$ and $\mathrm{p}>0.01$; conscientiousness, $r=-.047$ and $\mathrm{p}>0.05$ ), openness, $\mathrm{r}=0.069$ and $\mathrm{p}>0.05$; agreeableness, $\mathrm{r}=0.117$ and $\mathrm{p}>0.01$; and neuroticism, $\mathrm{r}=0.118$ and $\mathrm{p}>0.01$ ). Also, there was a positive relationship between leisure motivation and social well-being (social well-being, $r=0.028$ and $\mathrm{p}>0.05$ ). In addition, there was a positive relationship between leisure motivation, certain of its dimensions (competence/mastery, stimulus/avoidance, and social factors) and social well-being and a negative relationship between intellectual factors and social well-being. In this context, hypothesis H2: There is a positive relationship between students' personality traits, leisure motivation, and perception of social well-being was accepted. 
Table 3: The Relationships Connecting Personality, Leisure Motivation and Perception of Social Well-being

\begin{tabular}{|c|c|c|c|c|c|c|c|c|c|c|c|c|c|c|c|}
\hline Scale & $\mathbf{N}$ & Mean & St & 1 & 2 & 3 & 4 & 5 & 6 & 7 & 8 & 9 & 10 & 11 & 12 \\
\hline Personality & 516 & 3.4147 & .30056 & 1 & & & & & & & & & & & \\
\hline Leisure Motivation & 514 & 3.8297 & .58588 & $\begin{array}{l}.490^{* *} \\
.000\end{array}$ & 1 & & & & & & & & & & \\
\hline Social well-being & 514 & 4.2014 & .66117 & $\begin{array}{l}.149^{* *} \\
.001\end{array}$ & $\begin{array}{l}.028 \\
.534\end{array}$ & 1 & & & & & & & & & \\
\hline Extraversion & 516 & 3.0748 & .37979 & $\begin{array}{l}.597^{* *} \\
.000\end{array}$ & $\begin{array}{l}.226^{* *} \\
.000\end{array}$ & $\begin{array}{l}.156^{* *} \\
.000\end{array}$ & 1 & & & & & & & & \\
\hline Conscientiousness & 516 & 3.9331 & .82921 & $\begin{array}{l}.500^{* *} \\
.000\end{array}$ & $\begin{array}{l}.453^{* *} \\
.000\end{array}$ & $\begin{array}{l}-.047 \\
.283\end{array}$ & $\begin{array}{l}.172^{* *} \\
.000\end{array}$ & 1 & & & & & & & \\
\hline Openness & 515 & 3.2434 & .54736 & $\begin{array}{l}.502^{* *} \\
.000\end{array}$ & $\begin{array}{l}.287^{* *} \\
.000\end{array}$ & $\begin{array}{l}.069 \\
.117\end{array}$ & $\begin{array}{l}.246^{* *} \\
.000\end{array}$ & $\begin{array}{l}.228^{* *} \\
.000\end{array}$ & 1 & & & & & & \\
\hline Agreeableness & 516 & 3.2724 & .52921 & $\begin{array}{l}.441^{* *} \\
.000\end{array}$ & $\begin{array}{l}.225^{* *} \\
.000\end{array}$ & $\begin{array}{l}.117^{* *} \\
.008\end{array}$ & $\begin{array}{l}.215^{* *} \\
.000\end{array}$ & $\begin{array}{l}.167^{* *} \\
.000\end{array}$ & $\begin{array}{l}.082 \\
.062\end{array}$ & 1 & & & & & \\
\hline Neuroticism & 516 & 3,2074 & 99153 & $\begin{array}{l}.494^{* *} \\
.000\end{array}$ & $\begin{array}{l}.173^{* *} \\
.000\end{array}$ & $\begin{array}{l}.118^{* *} \\
.007\end{array}$ & $\begin{array}{l}.359^{* *} \\
.000\end{array}$ & $\begin{array}{l}.057 \\
.196\end{array}$ & $\begin{array}{l}.230^{* *} \\
.000\end{array}$ & $\begin{array}{l}.239^{* *} \\
.000\end{array}$ & 1 & & & & \\
\hline $\begin{array}{l}\text { Competence } \\
\text { /Mastery }\end{array}$ & 513 & 3.8716 & .77360 & $\begin{array}{l}.379^{* *} \\
.000\end{array}$ & $\begin{array}{l}.840^{* *} \\
.000\end{array}$ & $\begin{array}{l}.001 \\
.984\end{array}$ & $\begin{array}{l}.145^{* *} \\
.001\end{array}$ & $\begin{array}{l}.432^{* *} \\
.000\end{array}$ & $\begin{array}{l}.204^{* *} \\
.000\end{array}$ & $\begin{array}{l}.184^{* *} \\
.000\end{array}$ & $\begin{array}{l}.089^{*} \\
.044\end{array}$ & 1 & & & \\
\hline Intellectual factors & 514 & 3.9389 & .72837 & $\begin{array}{l}.499^{* *} \\
.000\end{array}$ & $\begin{array}{l}.782^{* *} \\
.000\end{array}$ & $\begin{array}{l}-.065 \\
.139\end{array}$ & $\begin{array}{l}.182^{* *} \\
.000\end{array}$ & $\begin{array}{l}.472^{* *} \\
.000\end{array}$ & $\begin{array}{l}.314^{* *} \\
.000\end{array}$ & $\begin{array}{l}.187^{* *} \\
.000\end{array}$ & $\begin{array}{l}.123^{* *} \\
.005\end{array}$ & $\begin{array}{l}.603^{* *} \\
.000\end{array}$ & 1 & & \\
\hline $\begin{array}{l}\text { Stimulus/ } \\
\text { Avoidance }\end{array}$ & 513 & 4.0138 & .78077 & $\begin{array}{l}.287^{* *} \\
.000\end{array}$ & $\begin{array}{l}.666^{* *} \\
.000\end{array}$ & $\begin{array}{l}.079 \\
.073\end{array}$ & $\begin{array}{l}.151^{* *} \\
.001\end{array}$ & $\begin{array}{l}.205^{* *} \\
.000\end{array}$ & $\begin{array}{l}.125^{* *} \\
.004\end{array}$ & $\begin{array}{l}.118^{* *} \\
.007\end{array}$ & $\begin{array}{l}.182^{* *} \\
.000\end{array}$ & $\begin{array}{l}.428^{* *} \\
.000\end{array}$ & $\begin{array}{l}.376^{* *} \\
.000\end{array}$ & 1 & \\
\hline Social factors & 512 & 3.6704 & .88992 & $\begin{array}{l}.288^{* *} \\
.000\end{array}$ & $\begin{array}{l}.672^{* * *} \\
.000\end{array}$ & $\begin{array}{l}.060 \\
.173\end{array}$ & $\begin{array}{l}.138^{* *} \\
.002\end{array}$ & $\begin{array}{l}.255^{* *} \\
.000\end{array}$ & $\begin{array}{l}.169^{* *} \\
.000\end{array}$ & $\begin{array}{l}.149^{* *} \\
.001\end{array}$ & $\begin{array}{l}.086 \\
.051 \\
\end{array}$ & $\begin{array}{l}.452^{* *} \\
.000\end{array}$ & $\begin{array}{l}.427^{* *} \\
.000\end{array}$ & $\begin{array}{l}.297^{* *} \\
.000\end{array}$ & 1 \\
\hline
\end{tabular}

** Correlation is significant at the 0.01 level (2-tailed). * Correlation is significant at the 0.05 level (2-tailed). 
The effect of the participants' personality traits and dimensions on leisure motivation is illustrated in Table 4.

Table 4: The Impact of Personality Traits and Related Dimensions on Leisure Motivation

\begin{tabular}{|c|c|c|c|c|c|c|}
\hline \multirow{2}{*}{$\begin{array}{c}\text { Dependent } \\
\text { Variable }\end{array}$} & \multirow{2}{*}{$\begin{array}{c}\text { Independent } \\
\text { Variable }\end{array}$} & \multicolumn{2}{|c|}{ Coefficient } & \multirow[t]{2}{*}{$\mathbf{t}$} & \multirow[t]{2}{*}{$\mathbf{F}$} & \multirow[t]{2}{*}{$\mathbf{R}^{2}$} \\
\hline & & $\beta$ & S. Error & & & \\
\hline \multirow{2}{*}{$\begin{array}{c}\text { Leisure } \\
\text { motivation }\end{array}$} & Constant & .571 & .257 & 12.725 & 161.928 & 0.240 \\
\hline & Personality & .954 & .075 & & & \\
\hline \multirow{6}{*}{$\begin{array}{l}\text { Leisure } \\
\text { motivation }\end{array}$} & Constant & 1.312 & .233 & 5.644 & 37.756 & 0.271 \\
\hline & Extraversion & .118 & .065 & 1.821 & & \\
\hline & Conscientiousness & .269 & .028 & 9.618 & & \\
\hline & Openness & .171 & .043 & 3.945 & & \\
\hline & Agreeableness & 131 & .045 & 2.927 & & \\
\hline & Neuroticism & .034 & .025 & 1.386 & & \\
\hline
\end{tabular}

The $\mathrm{F}$ value (161.928, see Table 4) indicates that the model was significant on all levels (Sig. $=0.000)$. It can be seen from the statistical $t$ values of the parameters that each variable included in the model was individually significant (at a 5\% significance level). Personality traits, whose $\beta$ value was 0.954 , positively affected leisure motivation. Personality traits positively affecting leisure motivation explained the motivation level at a rate of $0.240\left(\mathrm{R}^{2}=0.240\right)$. According to this result, the $24 \%$ change in leisure motivation was explained by the variable of personality traits. Consequently, hypothesis H3: Students' personality traits positively affect their leisure motivation was accepted.

As seen in Table 4, the F value (37.756) indicates that the model was significant as a whole, on all levels (Sig.=0.000). Moreover, the statistical $t$ values of the parameters that each variable included were individually significant (at the 5\% significance level). The $\beta$ values were found .118 for extraversion, .269 for conscientiousness, .171 for openness, .131 for agreeableness, and .034 all were dimensions of personality traits affecting leisure motivation. Conscientiousness, with the highest $\beta$ value of .269 affected leisure motivation the most and neuroticism, with the lowest $\beta$ value of .034 affected leisure motivation the least. Personality traits that affected leisure motivation explained the motivation level at a rate of $.271\left(\mathrm{R}^{2}=0.271\right)$. According to this result, the $27 \%$ change in leisure motivation was explained by the personality trait variables.

The effects of the participants' personality traits and associated dimensions on the perception of social well-being are displayed in Table 5. The $\mathrm{F}$ value (11.632) indicates that the model was significant as a whole, on all levels $(\mathrm{Sig} .=0.000)$. It can be seen from the statistical $\mathrm{t}$ values of the parameters that each variable was individually significant (at the 5\% significance level). Personality traits, with a $\beta$ value of .327 positively affected the perception of social well-being. Personality traits affecting the perception of social well-being explained the social well-being level at a rate of $0.022\left(\mathrm{R}^{2}=0.022\right)$. Considering this result, the $2 \%$ change in students' perception of social well-being was explained by the personality traits variable. In this case, hypothesis $H 4$ : Students' personality traits positively affect their perceptions of social well-being was accepted. 
Table 5: The Effects of Personality Traits and Related Dimensions on the Perception of Social Well-being

\begin{tabular}{clrrrrr}
\hline Dependent & Independent Variable & \multicolumn{2}{c}{ Coefficient } & t & F & $\mathbf{R}^{\mathbf{2}}$ \\
Variable & & $\boldsymbol{\beta}$ & \multicolumn{1}{c}{ S. Error } & & & \\
\hline Social well- & Constant & 3.084 & .329 & 3.411 & 11.632 & 0.022 \\
being & Personality & .327 & .096 & & & \\
\hline Social well- & Constant & 3.158 & .300 & 10.519 & 4.732 & 0.045 \\
being & Extraversion & .221 & .084 & 2.643 & & \\
& Conscientiousness & -.076 & .036 & -2.113 & & \\
& Openness & .050 & .056 & .893 & & \\
& Agreeableness & .124 & .058 & 2.134 & & \\
& Neuroticism & .030 & .032 & .928 & & \\
\hline
\end{tabular}

The $\mathrm{F}$ value (4.732) in Table 5 indicates that the model was significant as a whole on all levels (Sig. $=0.000)$. As can be seen from the statistical $t$ values of the parameters, each variable was individually significant (at the 5\% significance level). The $\beta$ values were .221 for extraversion, (.076) for conscientiousness, .050 for openness, .124 for agreeableness, and .030 for neuroticism; all were dimensions of personality traits affecting the perception of social well-being. Extraversion, with the highest $\beta$ value .221 was affected the perception of social well-being the most while conscientiousness, with the lowest $\beta$ value -.076 affected the perception of social well-being the least. Personality traits that affected social well-being explained the social wellbeing level at a rate of $0.045\left(\mathrm{R}^{2}=0.045\right)$. In this case, it appears that all dimensions except conscientiousness positively affected the perception of social well-being.

The effects of participants' leisure motivation and related dimensions on their perception of social well-being are illustrated in Table 6.

Table 6: The Effects of Leisure Motivation on the Perception of Social Well-being

\begin{tabular}{|c|c|c|c|c|c|c|}
\hline \multirow{2}{*}{$\begin{array}{l}\text { Dependent } \\
\text { Variable }\end{array}$} & Independent Variable & \multicolumn{2}{|c|}{ Coefficient } & \multirow[t]{2}{*}{$\mathbf{t}$} & \multirow[t]{2}{*}{$\mathbf{F}$} & \multirow[t]{2}{*}{$\mathbf{R}^{2}$} \\
\hline & & $\boldsymbol{\beta}$ & S. Error & & & \\
\hline \multirow{2}{*}{$\begin{array}{l}\text { Social well- } \\
\text { being }\end{array}$} & Constant & 4.084 & .193 & .622 & .387 & 0.001 \\
\hline & Leisure Motivation & .031 & .050 & & & \\
\hline \multirow{6}{*}{$\begin{array}{l}\text { Social well- } \\
\text { being }\end{array}$} & Constant & 4.109 & .194 & 21.228 & 3.015 & 0.023 \\
\hline & Competence /Mastery & .003 & .050 & .060 & & \\
\hline & Intellectual factors & -.131 & .052 & -2.550 & & \\
\hline & Stimulus/ & .089 & .042 & 2.138 & & \\
\hline & Avoidance & & & & & \\
\hline & Social factors & .066 & .038 & 1.763 & & \\
\hline
\end{tabular}

The F value (.387) shown in Table 6 indicates that the model was significant as a whole at all levels $(\mathrm{Sig} .=0.000)$. As can be seen from the statistical $t$ values of the parameters, each variable included in the model was individually significant (at the 5\% significance level). In general, leisure motivation whose $\beta$ value was .031 positively affected the perception of social well-being and explained the social well-being level at a rate of $0.001\left(\mathrm{R}^{2}=0.001\right)$. Considering this result, the $.01 \%$ change in students' perception of social well-being was explained by the variable of leisure motivation. In this case, hypothesis H5: Students' leisure motivation positively affects their perception of social well-being was accepted. 
The F value (3.015) illustrate in Table 6 demonstrates that the model was significant as a whole on all levels (Sig. $=0.000$ ). As can be seen from the statistical $t$ values of the parameters, each variable was individually significant (at the 5\% significance level). The $\beta$ values were .003 for competence/mastery, -.131 for intellectual factors, .089 for stimulus/avoidance, and .066 for social factors; all were dimensions of leisure motivation affecting the perception of social wellbeing. Stimulus/avoidance, whose $\beta$ value .089 was the highest, affected the perception of social well-being the most and intellectual factors, whose $\beta$ value -.131 was the lowest, affected the perception of social well-being the least. The dimensions of leisure motivation that affected social well-being explained the social well-being level at a rate of $0.023\left(\mathrm{R}^{2}=0.023\right)$. According to this result, the $2 \%$ change in students' perceptions of social well-being was explained by the variables representing the dimensions of leisure motivation. In this case, it was concluded that all leisure motivation dimensions except intellectual factors positively affected the perception of social well-being.

\section{Conclusions}

Personality is one of the most powerful and consistent predictors of well-being. There is also evidence of a genetic link between personality and well-being (Weiss, Bates, \& Luciano, 2008). In studies conducted on personality traits and well-being, extraversion and neuroticism were determined to be the most important for significantly predicting subjective well-being. A number of studies have also revealed that personality traits such as extraversion positively affect people; however, personality traits such as neuroticism have an adverse effect. (Aghababaei \& Arji, 2014; Jovanovic, 2011; Prabhakaran, Kraemer, \& Thompson-Schill, 2011; Steel, Schmidt, \& Shultz, 2008; Visser \& Pozzebon, 2013; Weiss et al., 2008). Personality traits are considered one of the most important predictors of individuals' well-being; their relationship with a wide variety of variables has been examined. To further this line of inquiry, their interactions with variables related to leisure motivation and social well-being investigated in this study. It was concluded that the perception of social well-being of the tourism students studied did not differ according to their age, gender, nationality, class, income, area of residence, or whether they lived with their parents $(H 1)$. The obtained results in this study are similar to the study results of Yurcu, Kasalak, and Akınc1 (2015). However, these results differ from those of Shapiro and Keyes (2008).

A positive relationship was found between leisure motivation and personality, dimensions related to leisure motivation and personality, and personality and social well-being. In addition, a positive correlation was revealed between personality, its dimensions (except conscientiousness, which showed a negative correlation), and social well-being. Finally, a positive relationship was identified between social well-being and leisure motivation, and leisure motivation's dimensions (excluding intellectual factors) and social well-being (H2).

General personality traits of tourism students positively affected their leisure motivation at a rate of $24 \%$. In addition, conscientiousness, one of the dimensions of personality traits, was identified as affecting leisure motivation the most. Personality traits had a positive influence on the variable of social well-being; the explanation rate was $4.5 \%$. When we examined the direction and rate at which the sub-dimensions of personality traits affected the variable of social wellbeing, it was found that conscientiousness had negative effect, extraversion affected social wellbeing positively. Although leisure motivation affected social well-being positively, the effect was minimal (0.001). Intellectual factors, one of the dimensions of leisure motivation, negatively 
affected social well-being, whereas other factors affected it positively. According to this result, it is thought that personality traits (except the intellectual factor) positively affect their leisure motivation $(H 3)$.

Joshanloo, Rastegar, and Bakhshi (2012) conducted a study on personality and concluded that neuroticism, one of the dimensions of personality traits, was negatively associated with social acceptance, social contribution and social compatibility; conscientiousness and social contribution were positively correlated. In addition, these researchers found openness to be positively related to social contribution and social compatibility; pleasantness, social acceptance, and social contribution were also connected. Moreover, no significant relationship between social well-being, its dimensions, and extraversion was found. Personality traits affected the level of social well-being at a rate of $28 \%(\mathrm{H} 4)$; the social well-being levels of male students were higher than those of female students. Similarly, Hill, Turiano, Mroczek, \& Roberts, (2012) determined that personality traits and social well-being were positively correlated.

The results of this research are similar to those of the studies conducted by Joshanloo et al., (2012) and Hill et al. (2012). The personality traits of the tourism students positively affected their leisure motivation and social well-being levels (H5). Some improvement in students' social well-being can be encouraged through recreational activities that comport with their particular personality traits. As level of social well-being increases, their physiological and psychological well-being will improve at a similar rate. Social isolation, which is becoming one of the most pressing problems in today's world, can be overcome, and students' awareness can be developed and taught through changes in behavior emphasized in the education process. If students try to have a positive life philosophy, and their level of awareness is improved and increased, they will provide the foundation for a healthy future society.

As in any research, this work has a number of limitations. Data were collected from just one university's student body, and thus cannot be generalized; however, the findings are still expected to contribute to future research. This research should be continued in a more detailed fashion, using more schools and students of tourism education. This will ensure that the relationships among personality traits, social well-being, and leisure motivation are properly analyzed.

\section{References}

Aghababaei, N., \& Arji, A. (2014). Well-being and the HEXACO model of personality. Personality and Individual Differences, 56(1), 139-142.

Aghaee, N. G., \& Ören, T. (2004, July). Effects of cognitive complexity in agent stimulation. Paper presented at Summer Computer Stimulation Conference, San Rose, California.

Akın, A., Demirci, İ., Çitemel, N., Sarıçam, H., \& Ocakçı, H. (2013, May). Sosyal iyi olma ölçeği Türkçe formu’nun geçerlik ve güvenirliği [Validity and reliability of the Turkish form of social well-being scale]. Paper presented at 5. Ulusal Lisansüstü Eğitim Sempozyumu, Sakarya, Türkiye.

Allport, G. W. (1961). Pattern and growth in personality. New York, NY: Holt, and Winston.

Bacanlı, H., İlhan, T., \& Aslan, S. (2009). Beş faktör kuramına dayalı bir kişilik ölçeğinin geliştirilmesi: Sıfatlara dayalı kişilik testi [Development of a personality scale based on five factor theory: Adjective based personality test (ABPT)]. Türk Ë̆itim Bilimleri Dergisi, 7(2), 261-279.

Barlı, Ö. (2008). Davranış bilimleri ve örgütlerde davranış [Behavioral sciences and organizational behavior] . Erzurum, Turkey: Aktif Yayınevi.

Beggs, B. A., \& Elkins, D. J. (2010). The influence of leisure motivation on leisure satisfaction. Retrieved from http://larnet.org/2010-02.html. 
Benet-Martínez, V., \& John, O.P. (1998). Los Cinco grandes across cultures and ethnic groups: Multitrait multimethod analysis of the big five in Spanish and English. Journal of Personality and Social Psychology, 75(3), 729-750.

Bloom, B. S. (1976). Human characteristics and school learning. New York, NY: McGraw Hill.

Bovee, C. I., Houston, M. J., \& Thill, J. V. (1995). Marketing (2 ${ }^{\text {nd }}$ ed.). New York, NY: Mcgraw Hill.

Breslow, L. (1972). A quantitative approach to the world health organization definition of health: Physical, mental and social well-being. International Journal of Epidemiology, 1(4), 347-355.

Church, M. K. (1993). Investigation and measurement of personality structure in a non-western culture: Relating indigenous Philiphinne dimensions to the big five model (Unpublished doctoral dissertation). Washington State University, Washington, DC.

Costa, P. T., \& Mccrae, R. R. (1995). Domains and facets: hierarchical personality assessment using the revised neo personality inventory. Journal of Personality Assessment, 64(1), 21-50.

Cüceloğlu, D. (2008). Insan ve davranışı: Psikolojinin temel kuramları [Human and behavior: Basic concepts of psychology], İstanbul, Turkey: Remzi Kitapevi.

Develioğlu, K., \& Tekin, Ö. A. (2013). Beş faktör kişilik özellikleri ve yabancılaşma arasındaki ilişki: Beş yıldızlı otel çalışanları üzerine bir uygulama [The relationship between five factor personality traits and alienation: An application on five-star hotel employees]. Süleyman Demirel University, Iktisadi ve İdari Bilimler Fakültesi Dergisi, 18(2), 15-30.

Emir, E. (2012). Rekreatif etkinliklere katılımın önündeki engellerin belirlenmesi: Üniversite öğrencileri örneği [Determination of the barriers to participation in recreational activities: Case of university students]. (Master's thesis, Karadeniz Technical University). Retrieved from http://ulusaltezmerkezi.com/rekreatifetkinliklere-katilimin-onundeki-engellerin-belirlenmesi-universite-ogrencileri-ornegi/20/

Erdoğan, İ. (1994). İşletmelerde davranış [Behavior in businesses], İstanbul, Turkey: Beta.

Eren, E. (2006). Örgütsel davranış ve yönetim psikolojisi. [Organizational behavior and management psychology]. İstanbul, Turkey: Beta.

Gökçe, H., (2008). Serbest zaman doyumunun yaşam doyumu ve sosyo-demografik değişkenlerle ilişskisinin incelenmesi [An analysis of the relationship between satisfaction and socio-demographic variables of free time satisfaction]. (Master's thesis). Retrieved from http://kutuphane.pamukkale.edu.tr/katalog/0057979.pdf

Günel, Ö. D. (2010). İşletmelerde psikoşiddet olgusu ve psikoşiddet mağdurlarının kişilik özelliklerine ilişkin bir araştırma [A study on personality traits of victims of psychosocial and psychosocial victims in enterprises]. Dokuz Eylül Üniversitesi Sosyal Bilimler Enstitüsü Dergisi, 12(3), 37-65.

Hill, P. L., Turiano, N. A., Mroczek, D. K., \& Roberts, B. W. (2012). Examining concurrent and longitudinal relations between personality traits and social well-being in adulthood. Social Psychological and Personality Science, 3(6), 698-705.

Jia, H. H. (2008). Relationships between the big five personality dimensions and cyberloafing behavior (Doctoral Dissertation). Available from ProQuest Dissertations and Theses database. (UMI No. 3320314).

John, O. P., \& Srivastava, S. (1999). Handbook of personality: Theory and research. New York, NY: The Gulliford.

John, O. P., Donahue, E. M., \& Kentle, R. L. (1991). The big five inventory-versions $4 a$ and 54. Berkeley, CA: University of California.

Joshanloo, M., Rastegar, P., \& Bakhshi, A. (2012). The big five personality domains as predictors of social wellbeing in Iranian university students. Journal of Social and Personal Relationships, 29(5), 639-660.

Jovanovic, V. (2011). Personality and subjective well-being: One neglected model of personality and two forgotten aspects of subjective well-being. Personality and Individual Differences, 50(2011), 631-635.

Keyes, C., L. (1998). Social well- being. Social Psychology Quarterly, 61(2), 121-140.

Kılınç, M., Ulucan, H., Kaya, K., \& Türkçapar, Ü. (2012). Takım sporu yapanların motivasyon düzeylerinin farklı değişkenlere göre düzenlenmesi [Regulation of motivation levels of team sports by different variables]. Abant İzzet Baysal Üniversitesi Ĕgitim Fakültesi Dergisi, 11(2), 133-144.

Lapa, T. Y., Ağyar, E., \& Bahadır, Z. (2012). Yaşam tatmini, serbest zaman motivasyonu, serbest zaman katılımı: Beden eğitimi ve spor öğretmenleri üzerine bir inceleme (Kayseri örneği) [Life satisfaction, leisure time motivation, leisure time participation: An examination on physical education and sports teachers (Kayseri City Example)]. SPORMETRE Beden Eğitimi ve Spor Bilimleri Dergisi, 10(2), 53-59.

Lucas, R. E., Diener, E., Grob, A., Suh, E.M., \& Shao, L. (200). Cross-cultural evidence for the fundamental features of extroversion. Journal of Personality and Social Psychology, 79(3), 452-468. 
Mccrae, R. R., \& Costa, P. T. (1992). Four ways five factors are basics. Personality and Individual Differences, 13(6), 653-665.

Moody, M. C. (2007). Adaptive behavior in intercultural environments: The relationship between cultural intelligence factors and big five personality traits (Unpublished doctoral dissertation). George Washington University, Washington, DC.

Morgan, C. T. (1999). Psikolojiye giriş [Introduction to psychology]. Ankara, Turkey: Meteksan.

Mutlu, İ., Yılmaz, B., Güngörmüş, H., A., Sevindi, T., \& Gürbüz, B. (2011). Bireylerin rekreasyonel amaçlı egzersize motive eden faktörlerin çeşitli değişkenlere göre karşıllanması [Fulfillment of exercise motivating factors for recreational purposes by various variables]. Selçuk Üniversitesi Beden Eğitimi, Spor Bilimleri Dergisi, 13(1), 54-61.

Ordun, G. (2004). Beş temel kişilik özelliği ve alt faktörlerinin analizine ilişkin bir çalışma [A study on the analysis of five basic personality traits and sub factors]. Istanbul Üniversitesi İşletme Fakültesi Dergisi, 2(33), 4771.

Perry, S. R. (2003). Big five personality traits and work drive as predictors of adolescent academic, performance (Doctoral dissertation), Retrieved from http://trace.tennessee.edu/cgi/viewcontent.cgi?article=3649\&context=utk_graddiss

Prabhakaran, R., Kraemer, D. J. M., \& Thompson-Schill, S. L. (2011). Approach, avoidance, and inhibition: personality traits predict cognitive control abilities. Personality and Individual Differences, 51(4), 439-444.

Shapiro, A., \& Keyes, C., L. (2008). Marital status and social well-being: Are the married always better off? Social Indicators Research, 88, 329-346.

Sintonen, H. (1981). An approach to measuring and valuing health states. Social Science \& Medicine, 15(2), 55-65.

Somer, O., Korkmaz, M., \& Tatar, A. (2002). Beş faktör kişilik envanterinin geliştirilmesi: Ölçek ve alt ölçeklerinin oluşturulması [Development of five factor personality inventory: Creating scale and subscales]. Türk Psikoloji Dergisi, 17(49), 21-33.

Steel, P., Schmidt, J., \& Shultz, J. (2008). Refining the relationship between personality and subjective well-being. Psychological Bulletin, 134(1), 138-161.

Tekin, E. G. (2014). Üniversite ögrencilerinin psikolojik iyi olma duygusal zeka ve sosyal iyi olma düzeyleri arasındaki ilişkilerin incelenmesi [Analysis of relationships among university students' psychological wellbeing, emotional intelligence and social well-being levels]. (Master's thesis, Sakarya University). Retrieved from https://tez.yok.gov.tr/UlusalTezMerkezi/TezGoster?key=48XPj7KKQhKUgntkUiKO3ORmbm5rJ1K9JEi3 Gnpvi03ZBffcmoksJnIfjsF3qkF6

Tınar, M. Y. (1999). Çalışma yaşamı ve kişilik [Working life and personality]. Istanbul, Turkey: Mercek Dergisi.

Tokat, B., Kara, H., \& Kara, M. Y. (2013). A-B tipi kişilik özelliklerine sahip işgörenlerin olası bir örgütsel değişime yatkınlıklarının araştırılması [Investigation of possible organizational change predictions of workers with type a-b personality traits]. Turkish Studies-International Peridical for the Languages, Literature and History of Turkish or Turkic, 8(8), 1973-1988.

Trouba, E. J. (2007). A person-organization fit study of the big five personality model and attraction to organizations with varying compensation system characteristics (Unpublished doctoral dissertation). DePaul University, Chicago, IL.

Üstün, Ü. D., \& Kalkavan, A., (2013, October-Novermber). Beden eğitimi ve spor yüksekokulu öğrencilerini rekreatif faaliyetlere katılmaya motive eden faktörlerin araştırlması [Investigation of factors that motivate physical education and sports students to participate in recreational activities]. Paper presented at II. Rekreasyon araştırmaları Kongresi, İzmir, Turkey.

Visser, B. A., \& Pozzebon, J. A. (2013). Who are you and what do you want? Life aspirations, personality, and well-being. Personality and Individual Differences 54(2), 266-271.

Weiss, A., Bates, T. C., \& Luciano, M. (2008). Happiness is a personal(ity) thing: The genetics of personality and well-being in a representative sample. Psychological Science, 19(3), 205-210.

Wortmann, C. B. (1988). Psychology. New York, NY: Alfred Knopf Inc.

Yurcu, G., Kasalak, M. A., \& Akıncı, Z. (2015). Otel çalışanlarının sosyal iyi olma algılarının demografik değişkenler açısından incelenmesi: Antalya ili örneği [Examination of hotel employees' perception of social well-being in terms of demographic variables: Antalya province example]. Journal of Tourism Theory and Research, 1(1), 8-21. 